\title{
PRODUCTIVE PEFORMANCE, NUTRIENTS DIGESTIBILITY AND SOME SERUM METABOLIC INDICES AS AFFECTED BY DIEATARY SUPPLEMENTATION OF COPPER AND ZINC IN EGYPTIAN BUFFALO CALVES
}

\author{
E.M. Ibrahim \\ Animal Production Department, Faculty of Agriculture, Minia University, El-Minia, Egypt.
}

(Received 6/6/2016, Accepted $29 / 7 / 2016$ )

\section{SUMMARY}

\begin{abstract}
$\mathrm{T}$ his study was designed to evaluate the effects of dietary supplementation of copper $(\mathrm{Cu})$ and zinc $(\mathrm{Zn})$ on productive performance, nutrients digestibility and some serum metabolic indices in Egyptian buffalo calves. A total number of 32 calves averaged $278.8 \pm 5.40 \mathrm{~kg}$ and 18 months old were divided into four equal groups ( 8 calves / each). Animals were fed on basal diet containing $4.38 \mathrm{mg} \mathrm{Cu}$ and $6.30 \mathrm{mg} \mathrm{Zn/kg}$ DM (control) supplemented with $10 \mathrm{mg} \mathrm{Cu}$ (T1), $30 \mathrm{mg} \mathrm{Zn} \mathrm{(T2)} \mathrm{and} 10 \mathrm{mg} \mathrm{Cu}$ plus $30 \mathrm{mg} \mathrm{Zn}$ (T3) /kg DM for 120 days. Digestibility of DM, NDF and ADF was higher $(\mathrm{P}<0.05)$ for calves fed T2 and T3 vs. T1 or control. The OM digestibility increased $(\mathrm{P}<0.05)$ for calves fed $\mathrm{T} 1, \mathrm{~T} 2$ and $\mathrm{T} 3$ vs. control. Calves fed on $\mathrm{T} 1, \mathrm{~T} 2$ and $\mathrm{T} 3$ had higher $(\mathrm{P}<0.05)$ digestibility of $\mathrm{CP}$ and $\mathrm{CF}$ than those fed control. Digestibility of $\mathrm{CP}$ and $\mathrm{CF}$ increased $(\mathrm{P}<0.05)$ with feeding $\mathrm{T} 3$ ration vs. each of $\mathrm{T} 1$ or $\mathrm{T} 2$ alone. The digestibility of $\mathrm{EE}$ increased $(\mathrm{P}<0.05)$ for calves fed $\mathrm{T} 3$ vs. those fed $\mathrm{T} 1$ or control rations. The digestible crude protein values were greater $(\mathrm{P}<0.05)$ with feeding $\mathrm{T} 1, \mathrm{~T} 2$ and $\mathrm{T} 3$ than control. The total digestible nutrients values increased $(\mathrm{P}<0.05)$ for calved fed on $\mathrm{T} 3$ when compared to control or $\mathrm{T} 1$. Results showed significant $(\mathrm{P}<0.05)$ increasing in final body weight for calves fed $\mathrm{T} 2$ and $\mathrm{T} 3$ vs. control or $\mathrm{T} 1$. The averages daily gain $(\mathrm{ADG})$ increased $(\mathrm{P}<0.05)$ for calves fed $\mathrm{T} 1, \mathrm{~T} 2$ and $\mathrm{T} 3$ vs. control. Also, ADG improved $(\mathrm{P}<0.05)$ for calves fed $\mathrm{T} 3$ vs. those of $\mathrm{T} 1$ and $\mathrm{T} 2$. In the same time, no significant changes were noticed in feed intakes (rice straw, concentrate feed mixture and total dry matter) among treatments vs. control, while digestible crude protein intake increased $(\mathrm{P}<0.05)$ for calves fed $\mathrm{T} 1, \mathrm{~T} 2$ and $\mathrm{T} 3$ vs. control. The total digestible nutrients intake increased $(\mathrm{P}<0.05)$ with $\mathrm{T} 3$ compared to control. Feed conversion was improved $(\mathrm{P}<0.05)$ for calves fed $\mathrm{T} 2$ and $\mathrm{T} 3$ vs. control. The $\mathrm{T} 2$ and $\mathrm{T} 3$ recorded higher $(\mathrm{P}<0.05)$ levels of serum total protein, albumin and globulin vs. control or T1. Serum globulin levels increased $(\mathrm{P}<0.05)$ in calves fed $\mathrm{T} 1$ vs. control. Feeding $\mathrm{T} 1$ decreased $(\mathrm{P}<0.05)$ serum cholesterol, but increased $(\mathrm{P}<0.05)$ HDL-cholesterol concentrations $v s$. control. The differences in serum glucose and triglycerides concentrations were not significant among calves in $\mathrm{T} 1, \mathrm{~T} 2$ and $\mathrm{T} 3$ vs. control. The present study indicated that dietary supplemental $\mathrm{Cu}$ plus $\mathrm{Zn}$ showed beneficial additive effects to improve nutritive values, productive performance and blood metabolic indices in buffalo calves.
\end{abstract}

Keywords: Buffalo calves, copper and zinc, productive performance, nutrients digestibility and serum metabolic indices.

\section{INTRODUCTION}

Optimal performance, production and metabolic functions require adequate intake of balanced trace elements in livestock. Trace elements as copper $(\mathrm{Cu})$ and zinc $(\mathrm{Zn})$ play an important role in animal's metabolism. Regular supply of both in animal' diets could improve performance, reproduction, immunity, vitamin metabolism and health (Yatoo et al., 2013). Cu has functions related to cellular respiration, bone growth, heart function, development of connective tissue, myelination of the spinal cord and erythrocyte production (McDowell, 2003). Also, $\mathrm{Cu}$ at physiological concentrations can alter lipid metabolism in

Issued by The Egyptian Society of Nutrition and Feeds 
ruminants (Engle, 2011). Deficiency of $\mathrm{Cu}$ in ruminants could be resulted in metabolic disorders, reduced feed intake, negative effect on feed efficiency and leading to growth retardation (Enjalbert et al., 2006). Zn plays an integral role in regulating a wide variety of body functions including cell division, growth, metabolism, and appetite control. At the same time, Zn deficiency can negatively affect the growth, reproduction and gene expression in ruminants (Underwood and Suttle, 1999). Generally, $\mathrm{Cu}$ and $\mathrm{Zn}$ are also important for thyroid activity due to their role in synthesis or conversion of thyroid hormones (Abdollahi et al., 2013).

The inter-relationships between $\mathrm{Cu}$ and $\mathrm{Zn}$ are complex. Supplementation of $\mathrm{Zn}$ at high levels might have an antagonistic effect on $\mathrm{Cu}$ absorption. Thus, intakes of large amount of $\mathrm{Zn}$ can reduce $\mathrm{Cu}$ concentrations in plasma and liver of cattle and sheep (Kincaid, 1999). Underwood and Suttle (1999) indicated that an interaction between $\mathrm{Cu}$ and $\mathrm{Zn}$ assumes practical significance when more $\mathrm{Cu}$ is added to ration. Therefore, dietary supplemental levels should be within a 1:3 up to $1: 5$ ratio of $\mathrm{Cu}: \mathrm{Zn}$ to maintain optimal status of both micronutrients (Larson, 2005). Supplementation of each micronutrient alone had been shown to improve performance and nutritive values in calves and bulls (Heidarpour et al., 2008 and Netto et al., 2014). However, limited information is available on the interactive effects of both $\mathrm{Cu}$ plus $\mathrm{Zn}$ on performance and nutrient digestibility in ruminants.

The present study was designed to investigate the effect of dietary supplemental $\mathrm{Cu}$ plus $\mathrm{Zn}$ on productive performance, nutrients digestibility, nutritive values and some related serum metabolic indices in buffalo calves.

\section{MATERIALS AND METHODS}

\section{Animals:}

A total number of 32 Egyptian buffalo calves averaged $278.8 \pm 5.40 \mathrm{~kg}$ and 18 months old were used to carry out this experiment at the cattle fattening project station belonging to El-Minia governorateSamalout, El-Minia during January to April 2014.

\section{Experimental design:}

The animals were divided into four equal groups ( 8 calves / each) and fed on concentrate feed mixture (CFM) to cover their nutrients requirements according to NRC (1996). The calculated concentrations of $\mathrm{Cu}$ and $\mathrm{Zn}$ in the CFM were $4.38 \mathrm{mg} / \mathrm{kg}$ DM and $6.3 \mathrm{mg} / \mathrm{kg}$ DM, respectively. According to NRC (1996), the requirements of $\mathrm{Cu}$ and $\mathrm{Zn}$ are $10 \mathrm{mg} \mathrm{Cu} / \mathrm{kg}$ diet and $30 \mathrm{mg} \mathrm{Zn} / \mathrm{kg}$ diet. The calves were fed on basal diet (control) supplemented with $10 \mathrm{mg} \mathrm{Cu}$ (T1), $30 \mathrm{mg} \mathrm{Zn} \mathrm{(T2)} \mathrm{and} 10 \mathrm{mg}$ Cu plus $30 \mathrm{mg} \mathrm{Zn/kg} \mathrm{DM} \mathrm{(T3)} \mathrm{for}$ 120 days. The inorganic sources of $\mathrm{Cu}$ and $\mathrm{Zn}$ were copper sulfate $\left(\mathrm{CuSO}_{4} \cdot 5 \mathrm{H}_{2} \mathrm{O}\right)$ and zinc sulfate $\left(\mathrm{ZnSO}_{4} .7 \mathrm{H}_{2} \mathrm{O}\right)$, respectively. The CFM contained $45 \%$ wheat bran, $25 \%$ yellow corn, $15 \%$ sunflower meal, $5 \%$ soybean meal, $7 \%$ rice bran, $2 \%$ calcium carbonate and $1 \%$ sodium chloride. In this experiment, rice straw (RS) as roughage source was offered ad libitum.

Animals were fed individually on the CFM and rice straw offered three times a day. The residual was weighed and the consumed amounts were calculated. Body weights of calves were recorded at the beginning of the experiment and at the end of each month during the experimental period. Averages daily gain and feed conversion of calves were calculated. Fresh water was available along the experiment. Buffalo calves were subjected to the routinely veterinary vaccination and inspection system.

\section{Sampling and laboratory analysis:}

Dietary samples were collected daily in the last week of each month along the experiment period and a composite sample was performed. A portion of the composite sample was dried at $105{ }^{\circ} \mathrm{C}$ in a forced air oven till constant weight for DM determination. The rest of composite sample was dried at $70{ }^{\circ} \mathrm{C}$ for a constant weight, ground and kept in closely tied jars for laboratory analysis.

Diets were analyzed for dry matter $(\mathrm{DM})$, organic matter $(\mathrm{OM})$, crude protein $(\mathrm{CP})$, crude fiber $(\mathrm{CF})$, ether extract (EE) and ash according to AOAC (2003). Neutral detergent fiber (NDF) and acid detergent fiber (ADF) were determined according to Goring and Van Soest (1970). Grab fecal samples were collected 
before feeding at 7 am and 2 pm for each calfe on days 24 and 27 of each month and mixed together, dried on $70{ }^{\circ} \mathrm{C}$ till constant weight and analyzed for DM, OM, CP, CF, NDF, ADF, EE and ash. Total tract digestibility of DM, OM, CP, CF, NDF, ADF and EE were determined using acid insoluble ash as an internal marker according to Van Keulen and Young (1977). Proximate analysis of CFM, RS and total mixed ration (TMR) are presented in Table (1).

Table (1): Proximate analysis of concentrate feed mixture (CFM), rice straw (RS) and total mixed ration (TMR) fed to buffalo calves on DM basis (\%).

\begin{tabular}{lccc}
\hline Item & CFM $^{*}$ & RS & TMR \\
\hline DM & 89.52 & 89.50 & 89.51 \\
OM & 90.65 & 91.28 & 90.86 \\
CP & 16.96 & 3.03 & 12.46 \\
EE & 3.06 & 1.79 & 2.65 \\
CF & 12.88 & 44.86 & 23.20 \\
NFE & 57.75 & 41.60 & 52.55 \\
NDF & 37.53 & 94.97 & 56.08 \\
ADF & 15.88 & 60.34 & 30.23 \\
Ash & 9.35 & 8.72 & 9.14 \\
\hline *: Concentrate feed mixture contained 45\% wheat bran, 25 \% yellow corn, 15 \% sunflower meal, 5 \% soybean meal, 7 \\
\% rice bran, 2 \% calcium carbonate and 1\% sodium chloride.
\end{tabular}

\section{Blood sampling and serum measurements:}

Monthly in the last week, blood samples were collected from the jugular vein of each animal at 8.00 am before feeding and drinking. Samples were left to clot at room temperature for at least $4 \mathrm{~h}$, then the clots were removed and sera were cleared by centrifugation at $1500 \times \mathrm{g}$ for $20 \mathrm{~min}$ and stored at $-20{ }^{\circ} \mathrm{C}$ for later assay. Serum total protein, albumin, and glucose were determined colorimetrically using commercial kits. Serum globulin concentrations were calculated by difference between total protein and albumin concentrations. Serum concentrations of cholesterol, triglycerides and high density lipoprotein (HDL) were analyzed colorimetrically by STAT LAB SZSL60-SPECTRUM, using commercial kits. The analysis was performed at Cairo University Research Park, Faculty of Agriculture, Cairo University.

\section{Statistical analysis:}

The data were analyzed by least square means analysis of variance using General Linear Model procedure of the statistical analysis system (SAS, 2000). The model used to analyze the different traits studied for calves was as follows:

$\mathrm{Y}_{\mathrm{ij}}=\mu+\mathrm{T}_{\mathrm{i}}+\mathrm{e}_{\mathrm{ij}}$.

Where: $\mathrm{Yij}=\mathrm{i}^{\text {th }}$ observation, $\mu=\mathrm{y}_{\mathrm{ij}}$, Population mean; $\mathrm{Ti}=$ Effect of $\mathrm{i}^{\text {th }}$ treatments and eij= Random error. Duncan's Multiple Range test was used to detect differences between means of the experimental groups (Duncan, 1955).

\section{RESULTS AND DISCUSSION}

\section{Nutrients digestibility and mutative value of diets:}

The results presented in Table (2) showed that digestibility of DM, NDF and ADF was higher $(\mathrm{P}<0.05)$ for calves fed $\mathrm{Z}$ and $\mathrm{Cu}$ plus $\mathrm{Zn}$ supplemented rations than those fed control or $\mathrm{Cu}$ alone. Also, the $\mathrm{OM}$ digestibility increased $(\mathrm{P}<0.05)$ with feeding $\mathrm{Cu}, \mathrm{Z}$ and $\mathrm{Cu}$ plus $\mathrm{Zn}$ supplemented rations vs. control. Calves fed $\mathrm{Cu}, \mathrm{Z}$ and $\mathrm{Cu}$ plus $\mathrm{Zn}$ supplemented rations had higher $(\mathrm{P}<0.05)$ digestibility of $\mathrm{CP}$ and $\mathrm{CF}$ than those fed control ration. In addition, $\mathrm{CP}$ and $\mathrm{CF}$ digestibility were higher $(\mathrm{P}<0.05)$ with feeding $\mathrm{Cu}$ plus $\mathrm{Zn}$ - 
supplemented rations than each of $\mathrm{Cu}$ or $\mathrm{Zn}$ alone. At the same time, the EE digestibility was increased $(\mathrm{P}<0.05)$ for calves fed $\mathrm{Cu}$ plus $\mathrm{Zn}$-supplemented ration $v s$. those fed $\mathrm{Cu}$ or control rations.

Table (2): Effects of $\mathrm{Cu}$ and $\mathrm{Zn}$ dietary supplementation on nutrients digestion coefficients and nutritive values of experimental treatments.

\begin{tabular}{|c|c|c|c|c|c|c|}
\hline \multirow{2}{*}{ Item } & \multicolumn{4}{|c|}{ Treatments } & \multirow{2}{*}{ SEM } & \multirow{2}{*}{ Sig. } \\
\hline & Cont. & $\mathrm{T} 1$ & $\mathrm{~T} 2$ & T3 & & \\
\hline \multicolumn{7}{|c|}{ Nutrients digestibility (\%) } \\
\hline DM & $66.54^{\mathrm{b}}$ & $67.45^{b}$ & $69.76^{\mathrm{a}}$ & $70.21^{\mathrm{a}}$ & 0.57 & $*$ \\
\hline $\mathrm{OM}$ & $67.51^{\mathrm{c}}$ & $70.68^{b}$ & $72.98^{\mathrm{a}}$ & $73.82^{\mathrm{a}}$ & 0.53 & $*$ \\
\hline $\mathrm{CP}$ & $67.76^{\mathrm{c}}$ & $70.41^{\mathrm{b}}$ & $70.67^{\mathrm{b}}$ & $72.56^{\mathrm{a}}$ & 0.30 & $*$ \\
\hline $\mathrm{EE}$ & $67.20^{\mathrm{b}}$ & $67.15^{\mathrm{b}}$ & $68.74^{a b}$ & $69.49^{\mathrm{a}}$ & 0.48 & $*$ \\
\hline $\mathrm{CF}$ & $61.84^{\mathrm{c}}$ & $63.31^{\mathrm{b}}$ & $63.48^{\mathrm{b}}$ & $65.20^{\mathrm{a}}$ & 0.28 & $*$ \\
\hline NDF & $48.39^{b}$ & $53.16^{\mathrm{a}}$ & $53.24^{\mathrm{a}}$ & $53.55^{\mathrm{a}}$ & 0.017 & $*$ \\
\hline $\mathrm{ADF}$ & $46.99^{\mathrm{b}}$ & $47.75^{b}$ & $48.18^{\mathrm{a}}$ & $48.91^{\mathrm{a}}$ & 0.35 & $*$ \\
\hline \multicolumn{7}{|c|}{ Nutritive value (\%) } \\
\hline DCP & $8.44^{\mathrm{c}}$ & $8.77^{\mathrm{b}}$ & $8.81^{\mathrm{b}}$ & $9.04^{\mathrm{a}}$ & 0.05 & $*$ \\
\hline TDN & $63.89^{\mathrm{c}}$ & $64.57^{\mathrm{c}}$ & $66.25^{\mathrm{b}}$ & $67.64^{\mathrm{a}}$ & 0.14 & $*$ \\
\hline
\end{tabular}

$a, b$ and $c$ : Means within the same row having different superscripts significantly different at $P<0.05$.

*: Significant at $P<0.05$.

T1: $\mathrm{Cu}(10 \mathrm{ppm}) . \quad T 2: \mathrm{Zn}(30 \mathrm{ppm}) . \quad T 3: \mathrm{Cu}(10 \mathrm{ppm})$ plus Zn $(30 \mathrm{ppm}) / \mathrm{kg} \mathrm{DM})$.

The data of nutritive values in Table $(2)$ showed that the DCP values were greater $(\mathrm{P}<0.05)$ with feeding $\mathrm{Cu}, \mathrm{Z}$ and $\mathrm{Cu}$ plus $\mathrm{Zn}$-supplemented rations than control. Also, a significant increase $(\mathrm{P}<0.05)$ in TDN values with feeding $\mathrm{Z}$ and $\mathrm{Cu}$ plus $\mathrm{Zn}$ supplemented rations when compared to control or $\mathrm{Cu}$ alone.

In the present study, supplemental $\mathrm{Cu}$ alone significantly $(\mathrm{P}<0.05)$ improved the digestibility of $\mathrm{OM}$, $\mathrm{CP}$ and $\mathrm{CF}$ and NDF, but, no significant changes were observed in digestibility of DM, EE and ADF (Table 2). These results are, partially, consistent with some reports dealt with the effect of dietary supplemental $\mathrm{Cu}$ on nutrients digestibility. For instance, digestibility of OM and CP, but not EE, NDF and ADF, was significantly increased in male lambs fed supplemental $\mathrm{Cu}$ at $10 \mathrm{mg} \mathrm{Cu} / \mathrm{kg} \mathrm{DM}$ (Dezfoulian et al., 2012). The obtained results are consistent with Zhang et al. (2007) who noticed no significant effect on DM, EE and ADF digestibility in goats fed 10 and $20 \mathrm{mg} \mathrm{Cu} / \mathrm{kg}$ DM. This improvement may be attributed to $\mathrm{Cu}$ enhanced ruminal fermentation. Also, similar results were reported in growing and finishing steers (Engle and Spears, 2000). It should be realized that there are several environmental, genetic and dietary factors including $\mathrm{Cu}$ concentration in the basal diet and level as well as duration of $\mathrm{Cu}$ supplementation, likely contribute to the differences observed between studies on nutrient digestibility response to supplemental $\mathrm{Cu}$ (Engle and Spears, 2001). Interactions of $\mathrm{Cu}$ with other elements such as $\mathrm{Mo}, \mathrm{S}$ and $\mathrm{Zn}$ as well as overall internal $\mathrm{Cu}$ homeostasis may also be implicated (Solaiman et al., 2006).

The presented results indicated that dietary supplemental $\mathrm{Zn}(30 \mathrm{pmm})$ improved $(\mathrm{P}<0.05)$ all nutrient digestibility (DM, OM, CP, CF, NDF and ADF), except EE digestibility, and the nutritive values of DCP and TDN (Table 2). These findings are in good agreement with similar observation that supplemental $\mathrm{Zn}$ had improved all nutrients digestibility, nutritive values (TDN and DCP) and feed efficiency in buffalo (Zeedan et al., 2009). The results also reinforced by a recent study showed that dietary Zn supplementation at $20 \mathrm{mg}$ of supplemental $\mathrm{Zn} / \mathrm{kg}$ of DM (Zn sulfate) increased ( $\mathrm{P}<0.05$ ) digestibility of CP and NDF, with significant improving in ADG as reported in sheep (Mallaki et al., 2015). In addition, digestibility of DM, $\mathrm{OM}, \mathrm{CP}$ and NDF were also reported to be improved with supplemental Zn in dairy goats (Salama et al., 2003). The significant improvement in CP and NDF noticed in the present study on buffalo calves and reported by others in sheep (Mallaki et al., 2015) and goats (Salama et al., 2003), may suggest a positive role for Zn supplementation in fiber digestion. The present results also agree with Garg et al. (2008) who found that dietary supplemental $\mathrm{Zn}$ at $20 \mathrm{mg} / \mathrm{kg}$ of DM improved ADF and cellulose digestibility in lambs. Such improved ADF digestibility was also shown in goats fed $20 \mathrm{mg} \mathrm{Zn/kg} \mathrm{of} \mathrm{DM} \mathrm{from} \mathrm{Zn} \mathrm{sulfate} \mathrm{(Jia} \mathrm{et}$ 
al., 2009). In male crossbred cattle bulls, feeding diet containing $32.5 \mathrm{mg} \mathrm{Zn} / \mathrm{kg} \mathrm{DM}$ was adequate to support normal growth and nutrients digestibility (Mandal et al., 2007).

The significant effect of dietary supplemental $\mathrm{Cu}$ or $\mathrm{Zn}$ alone in improving nutrients digestibility as shown in the present study, was significantly $(\mathrm{P}<0.05)$ more pronounced in the combined effect of both micronutrients (Table 2). Data showed that dietary supplemental $\mathrm{Cu}(10 \mathrm{ppm})$ plus $\mathrm{Zn}(30 \mathrm{ppm})$ improved $(\mathrm{P}<0.05)$ all nutrients digestibility (DM, OM, CP, CF, EE, NDF and ADF) when compared to control. In this combined treatment, there was an additive effect of $\mathrm{Cu}$ plus $\mathrm{Zn}$ to increase nutrients digestibility and nutritive values as DCP and TDN for calves than each of $\mathrm{Cu}$ or $\mathrm{Zn}$ alone.

The additive effect of both micronutrients in nutrients digestibility and growth could be discussed in the light of view that they act as components in numerous enzyme systems associated with carbohydrate and protein metabolism (Larson, 2005). In the same way, Jacob et al. (2010) concluded that the potential mechanisms of growth performance promotional effects of $\mathrm{Cu}$ and $\mathrm{Zn}$ may be referred to their antimicrobial activities in that gut microbial flora are altered to reduce fermentation loss of nutrients and to suppress gut pathogens.

\section{Productive performance:}

Calves fed $\mathrm{Zn}$ and $\mathrm{Cu}$ plus $\mathrm{Zn}$ supplemented rations showed a significant $(\mathrm{P}<0.05)$ increase in their final body weight (FBW) compared to those fed control or $\mathrm{Cu}$ alone (Table 3). Also, there were significantly $(\mathrm{P}<0.05)$ increases in average of daily gain $(\mathrm{ADG})$ for $\mathrm{Cu}, \mathrm{Zn}$ and $\mathrm{Cu}$ plus $\mathrm{Zn}$ supplemented calves vs. control. Also, average ADG improved $(\mathrm{P}<0.05)$ for calves fed $\mathrm{Cu}$ plus $\mathrm{Zn}$ supplemented rations $v s$. those of $\mathrm{Cu}$ or $\mathrm{Zn}$ alone. In addition, data of feed intake indicated no significant change in rice straw intake (RSI), concentrate feed mixture (CFM) and total dry matter intake (TDMI) due to experimental treatments. Meanwhile, digestible crude protein intake (DCPI) and total digestible nutrients intake (TDNI) were significantly $(\mathrm{P}<0.05)$ increased for calves fed on $\mathrm{Cu}, \mathrm{Zn}$ and $\mathrm{Cu}$ plus $\mathrm{Zn}$ supplemented calves $v$ s. control. Feed conversion $(\mathrm{FC})$ improved $(\mathrm{P}<0.05)$ for calves fed $\mathrm{Zn}$ and $\mathrm{Cu}$ plus $\mathrm{Zn}$ supplemented rations compared to control or $\mathrm{Cu}$ alone. Feed conversion of digestible crude protein (FC-DCP) and TDN (FCTDN) increased $(\mathrm{P}<0.05)$ for calves fed $\mathrm{Zn}$ and $\mathrm{Cu}$ plus $\mathrm{Zn}$ supplemented rations compared to control.

Table (3): Effects of $\mathrm{Cu}$ and $\mathrm{Zn}$ dietary supplementation on productive performance of buffalo calves.

\begin{tabular}{|c|c|c|c|c|c|c|}
\hline \multirow{2}{*}{ Parameters } & \multicolumn{4}{|c|}{ Treatments } & \multirow{2}{*}{ SEM } & \multirow{2}{*}{ Sig. } \\
\hline & Control & $\mathrm{T} 1$ & $\mathrm{~T} 2$ & T3 & & \\
\hline \multicolumn{7}{|l|}{ Body Weight: } \\
\hline IBW $(\mathrm{kg})$ & 282.2 & 278.2 & 280.0 & 274.7 & 5.40 & NS \\
\hline FBW $(\mathrm{kg})$ & $437.50^{\mathrm{b}}$ & $444.83^{\mathrm{b}}$ & $460.33^{\mathrm{a}}$ & $469.67^{\mathrm{a}}$ & 4.27 & $*$ \\
\hline ADG (kg/day) & $1.29^{\mathrm{c}}$ & $1.39^{\mathrm{b}}$ & $1.50^{\mathrm{b}}$ & $1.63^{\mathrm{a}}$ & 0.04 & $*$ \\
\hline \multicolumn{7}{|l|}{ Feed Intake $(\mathrm{kg} / \mathrm{d}$ : } \\
\hline RS & 4.18 & 4.23 & 4.13 & 4.12 & 0.04 & NS \\
\hline CFM & 8.77 & 8.72 & 8.72 & 8.66 & 0.08 & NS \\
\hline TDM & 12.93 & 12.95 & 12.85 & 12.78 & 0.12 & NS \\
\hline DCP & $1.09^{\mathrm{b}}$ & $1.13^{\mathrm{a}}$ & $1.14^{\mathrm{a}}$ & $1.16^{\mathrm{a}}$ & 1.39 & $*$ \\
\hline TDN & $8.26^{\mathrm{b}}$ & $8.36^{\mathrm{ab}}$ & $8.51^{\mathrm{ab}}$ & $8.64^{\mathrm{a}}$ & 0.11 & $*$ \\
\hline \multicolumn{7}{|l|}{ Feed Conversion: } \\
\hline FC (kg feed/kg gain) & $10.02^{\mathrm{a}}$ & $9.32^{\mathrm{a}}$ & $8.57^{\mathrm{b}}$ & $7.84^{\mathrm{b}}$ & 0.25 & $*$ \\
\hline FC-DCP (kg/gain) & $0.84^{\mathrm{a}}$ & $0.81^{\mathrm{ab}}$ & $0.77^{\mathrm{b}}$ & $0.71^{\mathrm{b}}$ & 0.02 & $*$ \\
\hline FC-TDN (kg/gain) & $6.40^{\mathrm{a}}$ & $6.01^{\mathrm{ab}}$ & $5.67^{\mathrm{b}}$ & $5.30^{\mathrm{b}}$ & 0.17 & $*$ \\
\hline \multicolumn{7}{|c|}{$a, b$ and $c$ : Means within the same row having different superscripts significantly different at $(P<0.05)$. } \\
\hline \multicolumn{7}{|c|}{ *: Significant at $(P<0.05)$} \\
\hline \multicolumn{7}{|l|}{ NS: Not significant. } \\
\hline Tl: $\mathrm{Cu}(10 \mathrm{ppm})$. & $T 2: Z n(3$ & & $\mathrm{Cu}(10 \mathrm{ppm}$ & us $\mathrm{Zn}(30 \mathrm{p}$ & $/ \mathrm{kg} D M)$. & \\
\hline
\end{tabular}


The present results indicated that supplemental $\mathrm{Cu}$ alone improved $(\mathrm{P}<0.05)$ the averages of ADG of buffalo calves could be related to the increase $(\mathrm{P}<0.05)$ in their $\mathrm{CP}$ digestibility, DCPI and nutritive value of DCP (Table 2). Also, the tendency of $\mathrm{Cu}$ to improve TDNI, FCR, FC-DCP and FC-TDN may be interacted in the positive effect of supplemental $\mathrm{Cu}$ on ADG. Similar effects of supplemental $\mathrm{Cu}$ on ADG were detected in dairy calves (Heiderpour et al., 2008), bulls (Netto et al., 2014) and male lambs (Hosienpour et al., 2014). In young Holstein bulls, supplemental $\mathrm{Cu}(30 \mathrm{mg} / \mathrm{kg} \mathrm{DM})$ improved their growth performance and decreases the prevalence of lameness (Fagari-Nobijari et al., 2013). In contrast, Datta et al. (2007) showed no significant effect of $\mathrm{Cu}$ supplementation on performance of goat kids or in steers and heifers (Felix et al., 2012).

In the present study, supplemental $\mathrm{Zn}$ alone had beneficial effect to improve productive performance such as FBW, ADG, FCR, DCPI, FC-DCP and FC-TDN of buffalo calves (Table, 3). These results are compatible with a previous report showed significant improvement in ADG and FC efficiency in growing buffalo calves fed $\mathrm{Zn}$ at $70 \mathrm{ppm}$ (Jadhav et al., 2008). In the same way, a significant increase in ADG and improvement in FCR has been reviewed with dietary supplemental $\mathrm{Zn}$ in beef cattle (Larson, 2005) and in sheep (Jafarpour et al., 2015). In the present study, the significant improvement in the previous parameters due to positive effect on attained nutrients digestibility and nutritive values of DCP and TDN for calves fed $\mathrm{Zn}$ supplemented-rations. Such beneficial effects of dietary supplemental $\mathrm{Zn}$ could be mediated enhanced metabolic processes and many enzymes systems, which are concern with the utilization and metabolism of feed nutrients that require $\mathrm{Zn}$ for proper functioning as an activator (McDowell, 2003). Supplemental Zn had improved all nutrients digestibility, nutritive values (TDN and DCP) and feed efficiency in buffalo calves (Zeedan et al., 2009). However, other report showed no improve in ADG or feed efficiency in finishing beef steers with dietary supplemental Zn (Malcolm-Callis et al., 2000).As far as the combined effect of $\mathrm{Cu}$ and $\mathrm{Zn}$ is concerned, the results showed a higher $(\mathrm{P}<0.05)$ improvement in ADG for calves fed $\mathrm{Cu}$ plus $\mathrm{Zn}$-supplemented calves than each of $\mathrm{Cu}$ alone or $\mathrm{Zn}$ alone (Table, 3). This finding may be revealed an additive effect for supplemental $\mathrm{Cu}$ plus $\mathrm{Zn}$ to improve performance of these treated calves. This additive effect of supplemental $\mathrm{Cu}$ plus $\mathrm{Zn}$ in enhancing ADG may be related to their significant effect to increase $\mathrm{CP}$ digestibility and nutritive values as shown in digestibility data. To the point, it was detected an improvement in ADG for calves grazing wheat pastures with the addition of both $\mathrm{Cu}$ and $\mathrm{Zn}$ which surpassed gains of cattle receiving either additional $\mathrm{Cu}$ only or $\mathrm{Zn}$ only (Larson, 2005). In addition, $\mathrm{Zn}$ may play an important role in the interactive combined effect with $\mathrm{Cu}$, since it has a critical role in proteolytic enzyme systems associated with muscle protein turnover in calves (Engle et al,. 1998).

The present study illustrated that the differences in feed intakes of RS, CFM and TDM were not significant differ among calves fed $\mathrm{Cu}, \mathrm{Zn}$ and $\mathrm{Cu}$ plus $\mathrm{Zn}$ supplemented diets vs. control (Table 3). This result is consistent with similar observations in bulls fed $\mathrm{Cu}$ at $40 \mathrm{mg} / \mathrm{kg}$ DM (Netto et al., 2014); and beef steers fed dietary supplemental Zn (Mandal et al., 2007).

\section{Serum metabolic indices:}

Data presented in Table (4) showed that calves fed $\mathrm{Z}$ and $\mathrm{Cu}$ plus $\mathrm{Z}$-supplemented diets had higher $(\mathrm{P}<0.05)$ values of serum total protein $(\mathrm{TP})$, albumin and globulin concentrations $v s$. control or $\mathrm{Cu}$ alone. Such increases could be attributed to a favorable role of $\mathrm{Zn}$, which is required for normal protein synthesis and metabolism. In addition, the significant effect of $\mathrm{Zn}$ in improving CP digestibility, DCPI and nutritive value DCP may be contributed to the favorable effect of $\mathrm{Zn}$ on serum TP and its fractions. The importance of $\mathrm{Zn}$ in the efficiency of utilizing absorbed amino acids in protein synthesis has been evidenced for growing calves (MacDonald, 2000). This response was also noticed in reports with dietary supplemental Zn on buffalo calves (Zeedan et al., 2009) and Friesian calves (Shakweer et al., 2010). Supplemental Zn may increase serum albumin via improved nitrogen absorption (Abu El-Ella et al., 2014); and increase globulin concentrations (El-Masry et al., 1998). Anyway, the values of serum TP, albumin and globulin, in the present study, were within the normal physiological ranges reported in bovine (Hussein et al., 2013). However, the present results disagree with some studies showed that, inorganic or organic $\mathrm{Zn}$ did not affect serum TP, albumin and globulin concentrations in sheep (Hassan et al., 2011) and dairy cattle (Sobhanirad and Naserian, 2012). While, calves fed $\mathrm{Cu}$-supplemented ration exhibited higher level of globulin vs. control (Table 4). Researches dealt with the effect of supplemental $\mathrm{Cu}$ upon blood protein profile are limited.

In the current study, although serum glucose concentrations were not significantly different among calves fed $\mathrm{Cu}, \mathrm{Zn}$ and $\mathrm{Cu}$ plus $\mathrm{Zn}$ supplemented rations vs. control (Table 4), their levels were maintained 
within the normal physiological ranges reviewed in bovine (Hussein et al., 2013). The results are in keeping with some studies working on cattle (Sobhanirad and Naserian, 2012) and sheep (Hosienpour et al., 2014 and Jafarpour et al., 2015).

Table (4): Effects of $\mathrm{Cu}$ and $\mathrm{Zn}$ dietary supplementation on some serum metabolites indices of buffalo calves.

\begin{tabular}{|c|c|c|c|c|c|c|}
\hline \multirow[t]{2}{*}{ Parameters } & \multicolumn{4}{|c|}{ Treatments } & \multirow{2}{*}{ SEM } & \multirow{2}{*}{ Sig. } \\
\hline & Control & $\mathrm{T} 1$ & $\mathrm{~T} 2$ & T3 & & \\
\hline Total protein $(\mathrm{g} / \mathrm{dl})$ & $6.62^{\mathrm{B}}$ & $6.90^{\mathrm{B}}$ & $7.80^{\mathrm{A}}$ & $7.91^{\mathrm{A}}$ & 0.47 & $* *$ \\
\hline Albumin (g/dl) & $3.00^{\mathrm{b}}$ & $3.10^{\mathrm{b}}$ & $3.72^{\mathrm{a}}$ & $3.83^{\mathrm{a}}$ & 0.12 & $*$ \\
\hline Globulin $(\mathrm{g} / \mathrm{dl})$ & $3.62^{\mathrm{c}}$ & $3.80^{\mathrm{b}}$ & $4.08^{\mathrm{ab}}$ & $4.08^{\mathrm{a}}$ & 0.09 & * \\
\hline Glucose $(\mathrm{mg} / \mathrm{dl})$ & 58.2 & 60.7 & 62.3 & 63.0 & 2.50 & NS \\
\hline Cholesterol (mg/dl) & $151.4^{\mathrm{a}}$ & $140.4^{\mathrm{b}}$ & $154.3^{\mathrm{a}}$ & $149.6^{\mathrm{ab}}$ & 5.54 & * \\
\hline $\mathrm{HDL}(\mathrm{mg} / \mathrm{dl})$ & $54.3^{\mathrm{b}}$ & $108.5^{\mathrm{a}}$ & $61.2^{\mathrm{b}}$ & $68.05^{\mathrm{b}}$ & 4.40 & $*$ \\
\hline Triglycerides $(\mathrm{mg} / \mathrm{dl})$ & 108.3 & 109.7 & 111.5 & 101.3 & 7.50 & NS \\
\hline
\end{tabular}

$a, b$ and $c$ :means within the same row having different superscripts significantly different at $(P<0.05)$.

*: Significant at $(P<0.05)$.

**: Significant at $(P<0.01)$.

NS: Not significant

HDL: High density lipoprotein

T1: $\mathrm{Cu}(10 \mathrm{ppm}) . \quad T 2: \mathrm{Zn}(30 \mathrm{ppm}) . \quad \mathrm{T3:} \mathrm{Cu}(10 \mathrm{ppm})$ plus $\mathrm{Zn}(30 \mathrm{ppm}) / \mathrm{kg} \mathrm{DM})$.

Data illustrated in Table (4) showed a decrease $(\mathrm{P}<0.05)$ in serum cholesterol concentrations concomitant with an increase in serum HDL with no significant changes in serum triglycerides for calves fed $\mathrm{Cu}$-supplemented ration vs. control. The decrease in serum cholesterol concentrations with dietary supplemental $\mathrm{Cu}$ was also detected in young Holstein bulls (Fagari-Nobijari et al., 2013). Similar responses of these lipid parameters were also noticed with dietary supplemental $\mathrm{Cu}$ in male fattening lambs diet (Hosienpour et al., 2014) and finishing steers (Engle et al., 2000). These results may be emphasized that dietary supplemental $\mathrm{Cu}$, at physiological concentrations, can alter plasma lipid metabolism in ruminants (Engle, 2011). The improving of endogenous antioxidant defenses and decreasing the oxidative stress may be implicated in supplemental $\mathrm{Cu}$ effect on lipid profile (Galhardi et al., 2005) However, some works showed no significant changes occurred in blood cholesterol with $\mathrm{Cu}$ supplementation in goats (Solaiman $e t$ al., 2006) and bulls (Netto et al., 2014). It was noticeable that supplemental Zn or Cu plus Zn had no significant effect on serum cholesterol, HDL and triglycerides concentrations compared to control. Similar observations were reported in beef steers (Malcolm-Callis et al., 2000), cattle (Sobhanirad and Naserian, 2012).

\section{CONCLUSION}

From the present study it can be concluded that the dietary supplementation of $\mathrm{Cu}(10 \mathrm{ppm})$ plus $\mathrm{Zn}$ (30 ppm), in basal diet containing $4.38 \mathrm{mg} \mathrm{Cu}$ and $6.30 \mathrm{mg} \mathrm{Zn} / \mathrm{kg} \mathrm{DM}$ showed beneficial additive effects to improve nutritive value, productive performance, and blood metabolic indices for buffalo calves.

\section{REFERENCES}

Abdollahi, E; H. Kohram and M.H. Shahir (2013). Plasma concentrations of essential microminerals and thyroid hormones during single or twin pregnancies in fat-tailed sheep. Small Ruminant Research. 113: 360-364. 
Abu El-Ella, A. A.; O. M. El-Malky and Kh. I. I. Zeedan (2014). Studies on using biogen-zinc on productive and reproductive performance of ruminants.1- physiological responses of Damascus goats to diet supplementation with biogen-zinc. Egypt. J. Sheep \& Goat Sci., 9: 29-48.

AOAC (2003). Association of Official Analytical Chemists. Official methods of analysis, $17^{\text {th }}$ ed., Arlington, USA.

Datta, C., M.K. Mondal and P. Biswas (2007). Influence of dietary inorganic and organic form of copper salt on performance, plasma lipids and nutrient utilization of Black Bengal (Caprahircus) goat kids. Anim. Feed Sci. Tech. 135:191-209.

Dezfoulian, A.H.; H. Aliarabi, M.M. Tabatabaei; P. Zamani; D. Alipour; A. Bahari and A. Fadayifar (2012). Influence of different levels and sources of copper supplementation on performance, some blood parameters, nutrient digestibility and mineral balance in lambs. Livestock Sci., 147: 9-19.

Duncan, D.B. (1955). Multiple range test and multiple F-test. Biometrics, 11: 1-42.

El-Masry, K. A.; H. M.Youssef; A. M. Abdel-Samee; I. F. M. Maria and M. K. Metawally (1998). Effects of supplemental $\mathrm{Zn}$ and vitamin $\mathrm{A}$ on some blood biochemical and immune indices related to growth performance in growing calves. First international conference on animal production and health in semiarid areas, El-Arish, Egypt, 1-3 Sept., 130-151.

Engle, T. E. (2011). Copper and lipid metabolism in beef cattle: A review. J. Anim. Sci. 89:591-596.

Engle, T. E.; C. F. Nockels; C. V. Kimberling; D. L. Weaber and A. B. Johnson (1998). Zinc repletion with organic or inorganic forms of zinc and protein turnover in marginally zinc-deficient calves, J. of Anim. Sci., 75:3074-3081.

Engle, T. E. and J. W. Spears (2000). Dietary copper effects on lipid metabolism, performance, and ruminal fermentation in finishing steers J. Anim. Sci. 78:2452- 2458.

Engle, T. E. and J. W. Spears (2001). Performance, carcass characteristics, and lipid metabolism in growing and finishing Simmental steers fed varying concentrations of copper. J. Anim. Sci. 79:2920-2925.

Engle, T. E.; J. W. Spears; T.A. Armstrong; C. L. Wright and J. Odle (2000). Effects of dietary copper source and concentration on carcass characteristics, lipid and cholesterol metabolism in growing and finishing steers. J. Anim. Sci. 78:53-1059.

Enjalbert, F.; P. Lebreton and O. Salat (2006). Effects of copper, zinc and selenium status on performance and health in commercial dairy and beef herds: Retrospective study. J. Anim. Physiol. Anim. Nutr. 90:459-466.

Fagari-Nobijari, H.; H. Amanlou and M. Dehghan-Banadaky (2013). The use of copper supplementation to improve growth performance and claw health in young Holstein bulls. J. Agr. Sci. Tech. 15: 77-86.

Felix, T.L.; W.P. Weiss; F.L. Fluharty and S.C. Loerch (2012). Effects of copper supplementation on feedlot performance, carcass characteristics, and rumen sulfur metabolism of growing cattle fed diets containing 60\% dried distillers grains. J. Anim. Sci. 90:2710-2716.

Galhardi, C.M.; Y.S. Diniz; H.G. Rodrigues; L.A. Faine; R.C. Burneiko; B.O. Ribas and E.L. Novelli (2005). Beneficial effects of dietary copper supplementation on serum lipids and antioxidant defenses in rats. Ann. Nutri. Metab., 49:283-288.

Garg, A. K.; M. Vishal and R. S. Dass (2008). Effect of organic zinc supplementation on growth, nutrient utilization and mineral profile in lambs. Anim. Feed Sci. Technol. 144:82-96.

Goring, H.K. and P. J. Van Soest (1970). Forage fiber analysis USDA. Agricultural hand book No. 379.

Hassan, A.A.; M.G. El-Ashry and S.M. Soliman (2011): Effect of supplementation of chelated zinc on milk production in ewes. Feed and Nutr. Sci. 2: 706-713.

Heidarpour B. M.; M. Mohri; H.D. Seifi and T.A.A. Alavi (2008). Effects of parenteral supply of iron and copper on hematology, weight gain and health in neonatal dairy calves. Vet. Res.Commun. 32, 553561 . 
Hosienpour, N.; M. A. Norouzian; A. Afzalzadeh; A. A. Khadem and A. A. Alamouti (2014). Source of copper may have regressive effects on serum cholesterol and urea nitrogen among male fattening lambs. Biol. Trace. Elem. Res., 159: 147-151.

Hussain , S. A.; S. K. Uppal., C. Randhawa; N. K. Sood and S. K. Mahajan (2013). Clinical characteristics, hematology, and biochemical analytics of primary omasal impaction in bovines. Turk. J. Vet. Anim. Sci., 37: 329-336.

Jacob, M.E.; J.T. Fox; T.G. Nagaraja; J.S. Drouillard; R.G. Amachawadi and S.K. Narayanan (2010). Effects of feeding elevated concentrations of copper and zinc on the antimicrobial susceptibilities of fecal bacteria in feedlot cattle. Foodborne Pathog. Dis., 7:643-648.

Jadhav S.E.; A.K. Garg and R.S. Dass (2008). Effect of graded levels of zinc supplementation on growth and nutrient utilization in male buffalo (Bubalus bubalis) calves. Anim. Nutr. and Feed Tech., 8 :6572.

Jafarpour, N., M. Khorvash; H. R. Rahmani, Pezeshki A. and G. M. Hosseini (2015). Dose-responses of zinc-methionine supplements on growth, blood metabolites and gastro-intestinal development in sheep. J. Anim. Phys. \& Anim. Nutr. Doi: 10.1111/jpn.12286.

Jia, W. B.; X. P. Zhu.; W. Zhang; J. Cheng; C. Guo and Z.H. Jia (2009). Effects of source of supplemental zinc on performance, nutrient digestibility and plasma mineral profile in Cashmere goats. Asian-Aust. J. Anim. Sci. 22: 1648 - 1653.

Kincaid, R. L. (1999). Assessment of trace mineral status of ruminants: A review. Proceeding of the American Society of Animal Science, pp: 1-13.

Larson, C. K. (2005). Role of trace minerals in animal production. Proc. Nutrition Conference sponsored by Department of Animal Science, UT, Extension and University Professional and Personal Development. University of Tennessee, USA.

MacDonald, R.S. (2000): The role of zinc in growth and cell proliferation. J. Nutr. 130: 1500S- 1058S.

Malcolm-Callis, K.J.; G.C. Duff; S.A. Gunter; E.B. Kegley and D.A. Vermeire (2000). Effects of supplemental zinc concentration and source on performance, carcass characteristics, and serum values in finishing beef steers. J. Anim. Sci., 78: 2801-2808.

Mallaki, M.; M. A. Norouzin and A. A. Khadem (2015). Effect of organic zinc supplementation on growth, nutrient utilization, and plasma zinc status in lambs. Turk. J. Vet. Anim. Sci., 39: 75-80.

Mandal, G. P.; R. S. Dass; D. P. Isore; A. K. Garg and G. C. Ram (2007). Effect of zinc supplementation from two sources on growth, nutrient utilization and immune response in male crossbred cattle (Bosindicus $\times$ Bostaurus) bulls. Anim. Feed Sci. Technol. 138:1-12.

McDowell, L. R. (2003). Minerals in Animal and Human Nutrition. $2^{\text {nd }}$ ed. Netherlands: Elsevier Science.

Netto, S.A.; M. A. Zanetti1; G. R. Del Claro; M. P. de Melo; F.G. Vilela, and L. B. Correa (2014). Effects of copper and selenium supplementation on performance and lipid metabolism in confined Brangus bulls. Asian Australian. J. Anim. Sci., 27: 488-494.

NRC (1996). National Research Council. Nutrient Requirements of Beef Cattle, $7^{\text {th }}$ Revised Edition, National Academy Press, Washington, D.C.

Salama, A. A. K.; G. Cajat; E. Albanell; X. Snch and R. Caslas (2003). Effects of dietary supplements of zinc methionine on milk production, udder health and zinc metabolism in dairy goats. J. Dairy Res. 70:9-17.

SAS (2000). SAS/STAT Guide for personal computers, SAS Inst., Cary. N.C., USA.

Shakweer, I. M.E.; A.A. M. EL-Mekass and H.M. EL-Nahas (2010). Effect of two different sources of zinc supplementation on productive performance of Friesian dairy cows. Egypt. J. Anim. Prod. 47:11-22. 
Sobhanirad, S. and A.A. Naserian (2012): Effects of high dietary zinc concentration and zinc sources on hematology and biochemistry of blood serum in Holstein dairy cows. Anim. Feed Sci. Technol., 177:242-264.

Solaiman, S. G.; C. E. Shoemaker; W. R. Jones and C. R. Kerth (2006). The effects of high levels of supplemental copper on the serum lipid profile, carcass traits, and carcass composition of goat kids. J. Anim. Sci. 84:171-177.

Underwood, E. J. and N. F. Suttle (1999). The mineral nutrition of livestock, $3^{\text {rd }}$ ed. CABI Publishing, CAB International.

Van Keulen, J. and B. A. Young (1977). Evaluation of acid insoluble ash as a natural marker in ruminant digestibility studies. J. Anim. Sci., 44:282.

Yatoo, M.I.; A. Saxena; P.M. Deepa; B.P. Habeab; S. Devi; R.S. Jatav and U. Dimri (2013). Role of Trace elements in animals: A Review, Vet. World, 6: 963-967.

Zeedan, K.H.; O.M. El-Malky and O.F. Komonna (2009). Productive and reproductive performance of buffaloes fed on rations supplemented with biogen zinc at late pregnancy period. Proc. of the 2nd Scientific Of Animals Wealth Research in the Middle East \& North Africa, Pp. 237-294.

Zhang, W.; R. Wang; X. Zhu; D. O. Kleemann; C. Yue and Z. Jia (2007). Effects of dietary copper on ruminal fermentation, nutrient digestibility and fiber characteristics in Cashmere goats. Asian-Aust. J. Anim. Sci. 20: 1843 -1848. 
الأداء الإنتاجى ، معـاملات الهضم وبعض المؤشرات الحيويـة للسيرم المتأثره بالإمداد الغذائى بعنصرى النحساس والزنك فى علائق عجول الجاموس المصرى

\author{
عماد الدين تحمه إبراهيم \\ قسم الإتتاج الحيوانى، كلية/لنزراعة، جامعة المنيا، مصر.
}

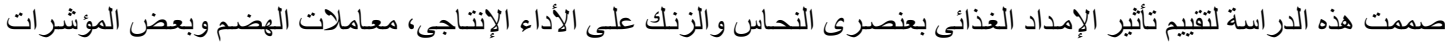

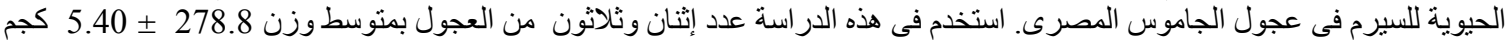

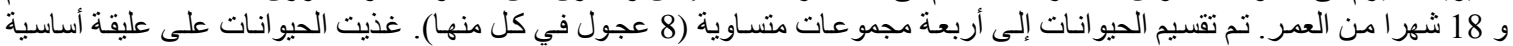

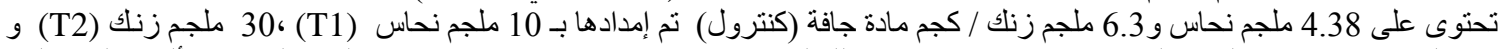

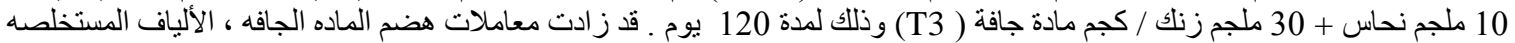

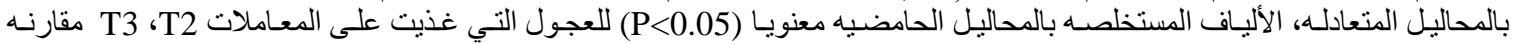

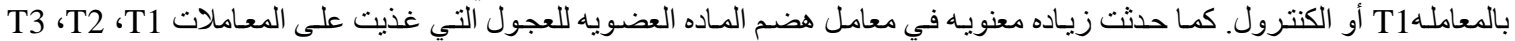

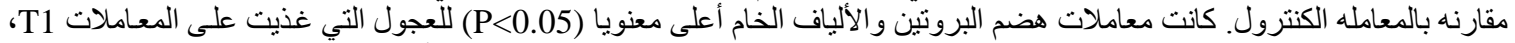

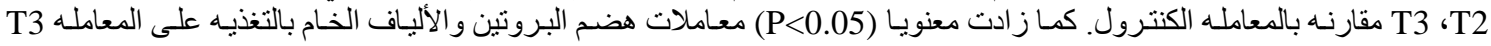

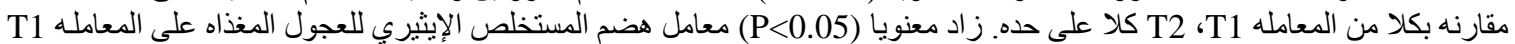

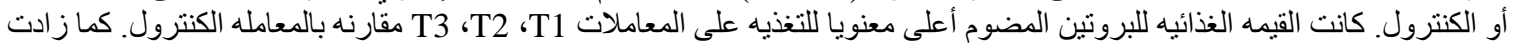

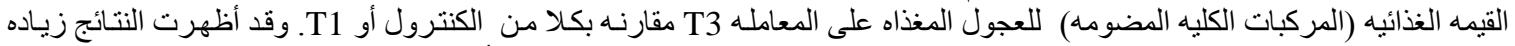

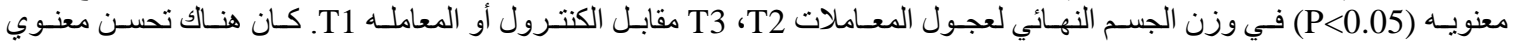

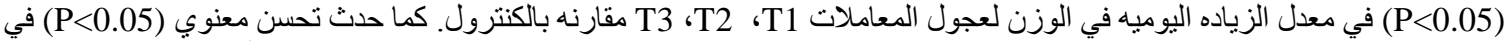

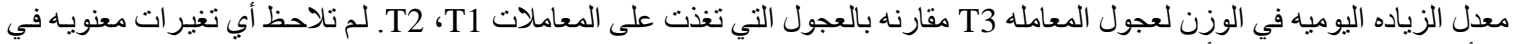

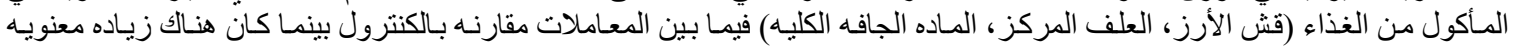

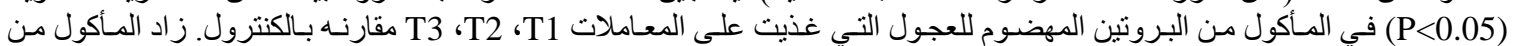

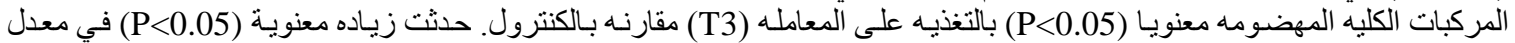

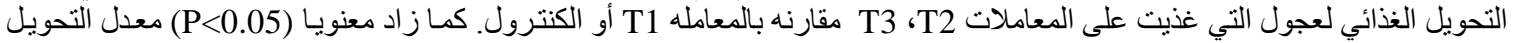

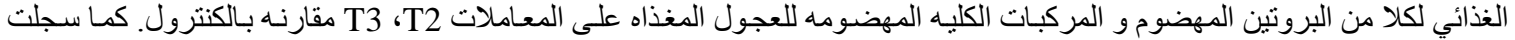

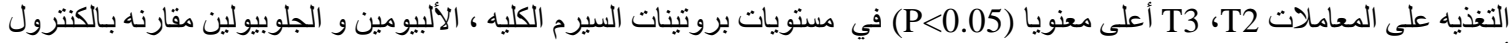

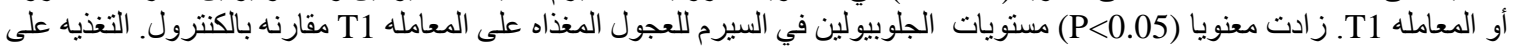

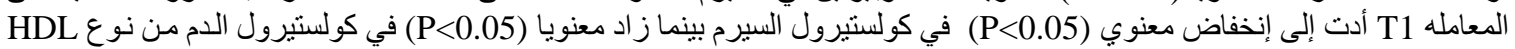

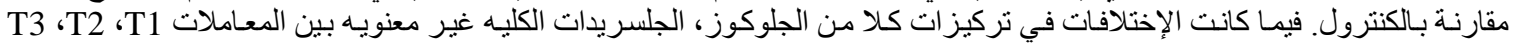
مقارنه بالكنترول.

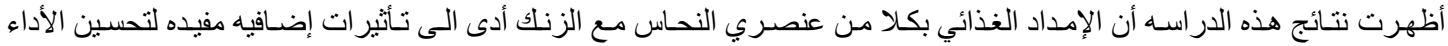

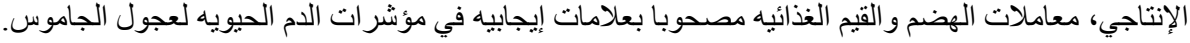

